\title{
Post-mining excellence: strategy and transfer
}

\author{
by J. Kretschmann
}

\section{Synopsis}

In 2007, a political understanding was arranged to phase out German hard coal mining (GHCM) in a socially acceptable manner by the end of 2018 , after more than 200 years of production. This decision required a new strategy in order to prepare the GHCM industry for the post-mining era. To create a sustainable development strategy (SDS), the long-term impacts of GHCM activities concerning the environmental, economic, and social dimensions were analysed systematically and forward-looking. High technical standards in environmental protection and post-mining technologies, and experiences in the development of former mine sites to create jobs, are significant from an international point of view. Besides, the cultural heritage of the mining era was preserved and developed for new purposes. The SDS of the GHCM industry can serve as a role model for mining regions facing similar challenges.

Keywords

sustainable development strategy, German hard coal mining, post-mining era.

\section{Introduction}

Principally, mining is a finite business that reaches its end if the deposits are depleted or the raw materials can no longer be mined in an economically profitable way. However, the impact of mining is potentially an infinite one - at least if measured at a human time-scale. Mining always means interfering with geological and ecological systems that cannot be returned to their original condition.

In general, the mining cycle can be divided into three phases:

1. The exploration phase, in which the deposit is investigated to determine its technical feasibility and economic profitability. The period of these undertakings is relatively short and can lead to the launch of mining operations.

2. What follows is the actual mining phase, which usually lasts for a long time and ends at the latest when all deposits are fully depleted. This lifespan may be shortened if the economic conditions (production cost or market price) deteriorate.

Nevertheless, mining may be resumed if those conditions become favourable once more (examples are silver mining in Germany or rare earth mining in the USA).

3. The longest phase, however, is the post-mining phase as human interference in geology and nature is usually intensive and irreversible. Mining can lead to consequences that have a permanent adverse impact on people and the environment; therefore, they have to be managed optimally (Kretschmann and Hegemann, 2012).

In the past, mining companies paid the most attention to the first two phases of the cycle, as those were the ones in which they could act profitably in the market. Moreover, many mining nations had not created a legal framework that would oblige companies to handle the impact of active mining in the postmining phase. As a result, the medium- and long-term impacts that the environment and the people living in the mining regions had to endure were often neglected - and even the economic impact was neglected. Remediating mining damage that occurred years later, such as subsidence damage or the restoration of land and water bodies, represents costs that the entire society has to cover if the funding by the mining companies is not properly defined. In the end, such impacts can lead to a loss of acceptance in politics and among the population. In Germany, the mining companies or their legal successors have to cover the costs. If the former owner is unknown, the federal state has to cover them (Kretschmann 2015).

The objective of this paper is to describe the end of the German hard coal mining industry and the strategy to successfully

* TH Georg Agricola University, Bochum, Germany.

(C) The Southern African Institute of Mining and Metallurgy, 2018. ISSN 2225-6253. This paper was first presented at the Society of Mining Professors 6th Regional Conference 2018, 12-13 March 2018, Birchwood Hotel and Conference Centre, Johannesburg, South Africa. 


\section{Post-mining excellence: strategy and transfer}

control and manage the challenges, risks, and opportunities of the post-mining era. This strategy is based on a concept of sustainable development of the mining region. Possibilities for knowledge transfer to South Africa are outlined, as well as the necessity of specialized post-mining education.

\section{Sustainability and post-mining}

If mining is to be as sustainable as possible, all three phases of the entire cycle have to be integrated, and the requirements of the post-mining phase have to be included in the strategic planning and the operations. As mining cannot be carried out without impact, it is necessary that negative consequences are minimized.

Sustainable development is defined as development that 'meets the needs of the present without compromising the ability of future generations to meet their own needs' (United Nations, 1987, p. 16).

Sustainability is about three basic aims: the sharing of wealth among as many people as possible (social sustainability), a durable and positive economic development (economic sustainability), and the preservation of nature (environmental sustainability) (Kretschmann, 2014).

This three-dimensional approach to sustainability can easily be transferred to post-mining activities. Sustainable management of mining impacts means that environmental damage caused by emissions, subsidence, and such factors should be limited (environmental dimension); the cost of managing both mining damage and permanent tasks should be kept as low as possible (economic dimension); and the population living in the mining regions should be offered future prospects to ensure their standard of living and their well-being after mining has come to an end (social dimension).

\section{Hard coal mining in Germany: From industrialization to post-mining}

In Germany, industrial underground mining of hard coal began in the early 19th century. In the Ruhr area, the main coal mining area in Germany, one of the biggest industrial agglomerations in Europe, with more than 5 million inhabitants, was built on coal between 1830 and 1930 (Figure 1).

For more than a hundred years, hard coal from domestic production had been the basis for industrial success in Germany, even after World War II, when Germany started its 'economic miracle', becoming one of the leading economies in the world. However, since the late 1950s, hard coal mining in Germany has been in a state of continuous decline. Because of high production costs due to the challenges of mining conditions at depths up to $1500 \mathrm{~m}$, hard coal mining in Germany could not continue to compete on the world coal market. More than 170 mines have been closed. The number of employees has decreased from about 500000 to 6000 . Coal production fell from $150 \mathrm{Mt} / \mathrm{a}$ in 1957 to $4 \mathrm{Mt} / \mathrm{a}$ in 2016 (RAG, 2017, p. 6; Statistik der Kohlenwirtschaft, 2017, p. 26). In 1968, the remaining mining companies in the Ruhr area merged their coal activities under the supervision of the so-called Ruhrkohle AG. Hard coal production received state subsidies to ensure supply for domestic power generation, the supply of coking coal, and to maintain jobs in mining. In 1997, Ruhrkohle AG was restructured and received a new name, RAG Aktiengesellschaft (RAG). The operation of the mines was step-by-step separated from the other business units in order to optimize funding opportunities and to draw a line between profitable and subsidized business activities.

In 2007, the German government decided to end financial support for the coal mining industry in 2018 because the European Union no longer allows such subsidies. This has led to a final mining closure programme.

The German government has passed a law on funding the termination of hard-coal mining. Based on this law, the 'old' RAG was split into three parts (Figure 2): a newly set up foundation, the RAG-Stiftung (RAG-foundation); the subsidized coal mining unit plus coal trade, land management, site development, and a few other coal-related service companies, still named ('new') RAG; and profitable business units, mainly the subsidiary Evonik Industries, one of the world's leading specialty chemicals companies, beside other interests. RAG-Stiftung holds $100 \%$ of the shares of
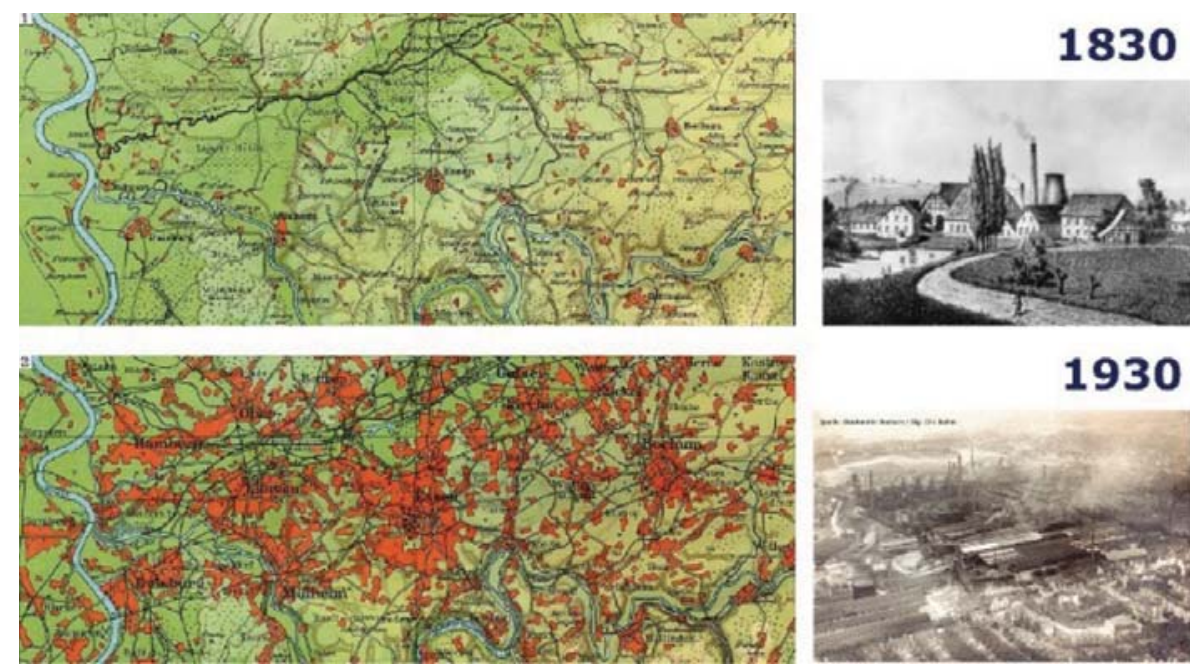

Figure 1-The Ruhr, one of the biggest industrial agglomerations in Europe, was built on coal (City Archive of Bochum/Compilation Christoph Dahm) 


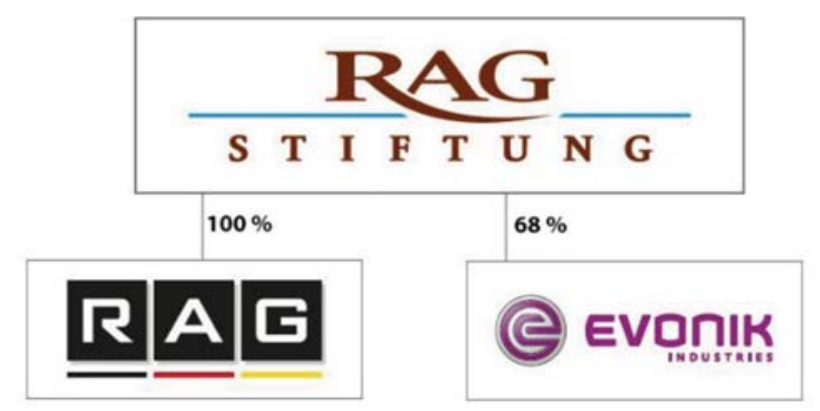

Figure 2-Company structure of the RAG-Stiftung/RAG (RAG-Stiftung, 2015)

RAG and $68 \%$ of the shares of Evonik Industries. The foundation has to ensure that the proceeds from the profitable business units will be used to provide sustainable funding for post-mining tasks so that German taxpayers will not have to pay for them. In addition, the RAG-Stiftung has the responsibility for promotion and support of education, sciences, and culture in the mining regions (RAG-Stiftung 2017).

Germany has long experience with mine closure, starting in the 1960s. At that time, the German government decided on an adjustment process that would reduce the social consequences of mine closure. To do so, the mining companies worked in close collaboration with political institutions and trade unions. The objective, until today, has been to achieve the economically necessary downsizing of staff without resulting in excessive unemployment in the mining regions. This objective could be achieved by means of a number of measures, such as the different ways that collective bargaining offered (e.g. agreements of early retirement), by attracting new employers to the manufacturing industry, and by establishing universities. This structural change in the economy was accompanied by the assignment of new land use functions to closed mining areas. Many of these areas became monuments of industrial heritage that are now open to the public, and the brownfield sites were restored for recreational and environmental purposes, and even for new commercial use.

Since the end of mining has been definitely decided, RAG is transforming from an active hard-coal producer to a postmining developer group. RAG has to master the organizational and technical challenges of mine closure in such a manner that any harm to people or damage to the environment is avoided or offset.

RAG has published a sustainability reporting structure that emphasizes the three columns of its sustainable development strategy: environment (post-mining), society and finances (employees and company), and humanity (cultural and social life). A very important aspect of developing a sustainability strategy is a continuous, open, and transparent dialogue with stakeholders and the general public. In the course of this dialogue, the challenges of postmining should be intensively discussed. In order to summarize the outcome of this dialogue as the basis of its sustainable development strategy, RAG has defined ten spheres of activity (Figure 3).
The CEO of RAG Group, Bernd Tönjes, has summarized the motivation of RAG to develop its sustainable development strategy as follows:

'At the end of the year 2018 the German hard coal mining will end. [In] more than 200 years it has transformed villages into cities and industrial centress. For many decades coal provided economic power for the mining regions and the whole federal republic. Mining has shaped visibly the landscapes, even after the end of the production. Its impacts are noticeable. But the unavoidable impacts can be regulated and mitigated in a responsible way. We are meeting the challenge to take responsibility for the impacts of coal mining - even when the time of an active mining is over.' (RAG, 2015).

One of many examples where all three dimensions of sustainability have been combined in order to reshape a former mining site is the 'Kreativ.Quartier Lohberg' (Figure 4). This development project illustrates the transformation of a former industrial centre into the first $\mathrm{CO}_{2}$-neutral suburb in Germany. An important feature of this site is the combination of modern and listed architecture that is completely supplied by renewable energy resources like photovoltaic plants, heat from minewater, biomass, wind turbines, and geothermal energy (Steinkohle, 2016).

\section{Risk management in German post-mining}

The general public perceives only the 'tip of the iceberg' (Figure 5) when it comes to the impact of underground mining, as the challenges of the development of the entire post-mining underground environment remain hidden.

With particular regard to post-mining the mining companies, in close collaboration with the mining authorities, have developed a risk management system that facilitates the recognition of all risks and the definition of suitable mitigation measures.The risk areas of abandoned mine sites can be divided into the following categories:

$>$ Near-surface cavities

> Surface openings, old shafts

> Subsidence, uplift

$>$ Discontinuous faults

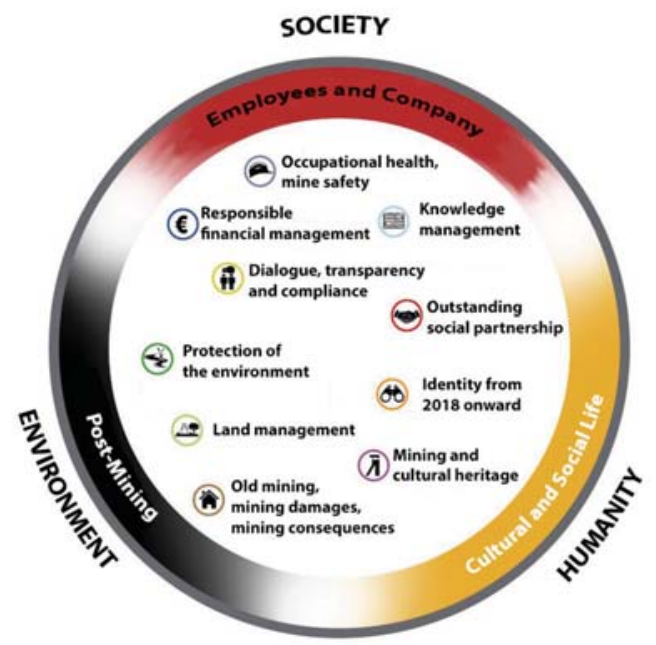

Figure 3-Ten spheres of activity in the sustainable development strategy of RAG (RAG 2015) 


\section{Post-mining excellence: strategy and transfer}

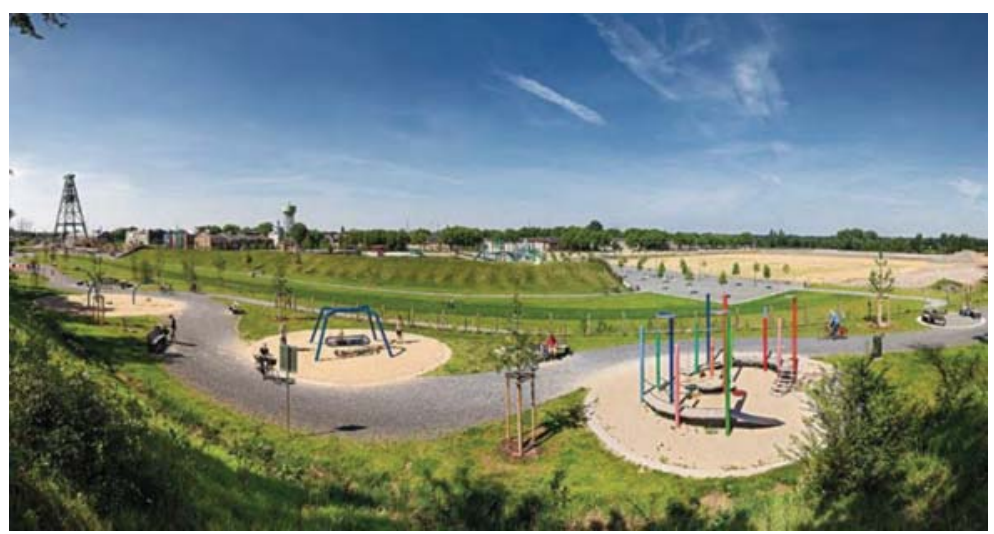

Figure 4-Kreativ.Quartier Lohberg. Overview of the former industrial centre that is being transformed into the first $\mathrm{CO}_{2}$-neutral suburb in Germany (Steinkohle, 2016. Photo by Dietmar Klingenburg)

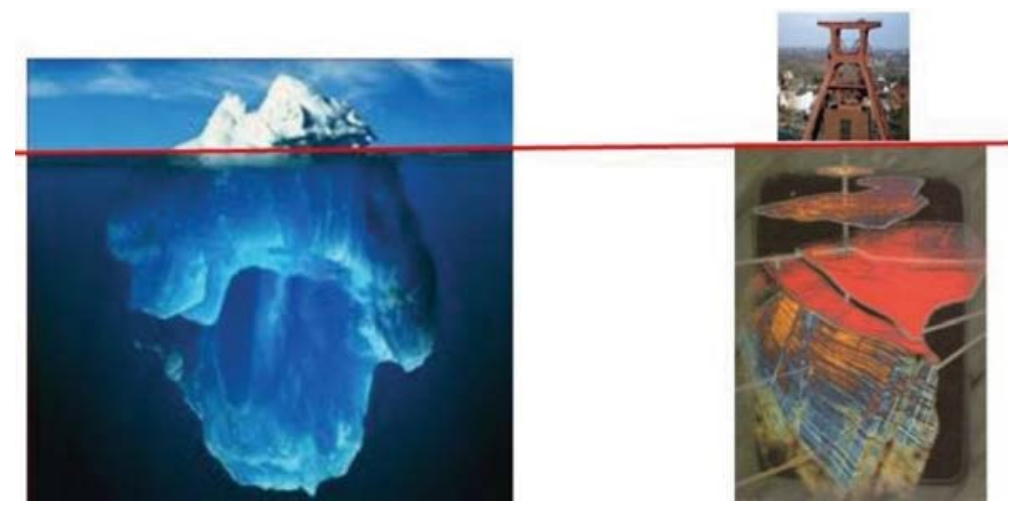

Figure 5-Challenges in German post-mining (the iceberg model)

$>$ Mine gas emission at the surface

$>$ Surface water

$>$ Pumping of minewater

- Refuse dumps

$>$ Operation areas (brownfield).

According to the post-mining risk areas, RAG has defined a number of environmental challenges, which have been divided into two groups: legacy and perpetual tasks. Legacy includes the old mine structures like former operation areas (collieries, coking plants), slag and coal heaps, etc.; the remediation of mining damage caused by e.g. subsidence or uplift; and the securing of abandoned shafts and former nearsurface mining panels. Perpetual tasks include measures to handle minewater drainage, landfilling where mining subsidence occurs, and the cleaning up of groundwater at former mining locations (Figure 6). The distinction between legacy and perpetual tasks is especially relevant for the funding. Whereas RAG has made provisions for the legacy cost, the perpetual tasks are to be paid for by the RAGStiftung. From 2019 onwards, approximately 220 million euros will be spent each year by the RAG-Stiftung to handle these tasks (RAG-Stiftung, 2015). In both cases, however, RAG will be in charge of the operating measures.

Minewater drainage is probably the biggest and most expensive challenge among the perpetual tasks. Currently,
RAG pumps 70 million cubic metres of minewater per year out of its three coalfields (RAG, 2015). Where all mining operations have been closed, future water drainage is particularly important to avoid contamination of ground and drinking water by minewater in the regions.

\section{Opportunities from post-mining}

Until recently, post-mining management has focused on avoiding and preventing risks. However, in the risk management context, sustainability requires a holistic view of the mining cycle, including the opportunities that arise from abandoned mining sites. An effective post-mining strategy provides numerous opportunities for avoiding, mitigating, or even utilizing the risks by reinventing brownfield sites to create new jobs. What principally matters is the successful control and management of post-mining risks and the effective use of opportunities.

In the past few years, the German energy industry has undergone fundamental changes. Some key factors in this context are the finite nature of fossil fuels, global warming, $\mathrm{CO}_{2}$ emissions, and the risks of nuclear power. Therefore, German politics has incorporated these issues into the mission to move towards renewables without $\mathrm{CO}_{2}$ emissions, with initiatives such as solar energy, wind power, and 


\section{Post-mining excellence: strategy and transfer}

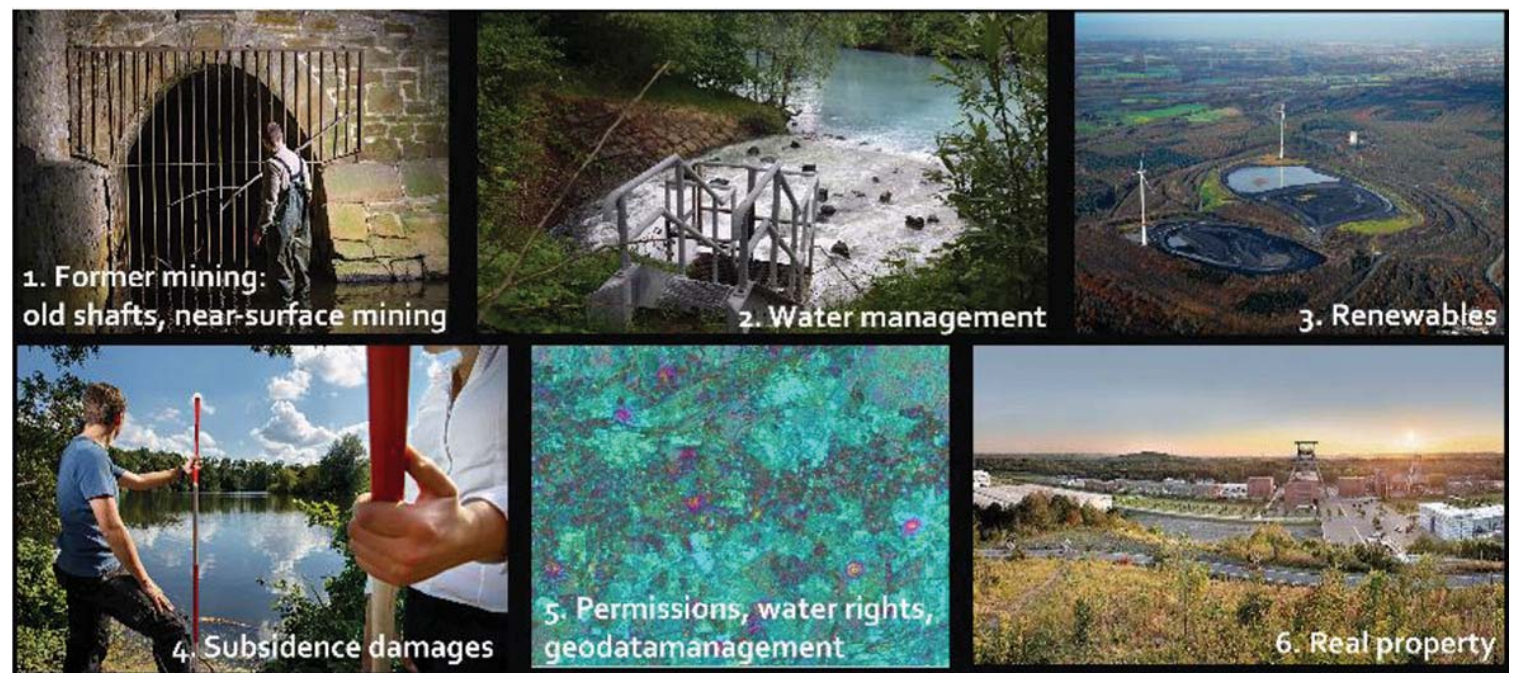

Figure 6-Burdens and perpetual tasks. (1-3 ๑RAG; 4. ๑THGA; 5. JERS data ๑JAXA, SAR and InSAR processing by Gamma Remote Sensing AG, 1998; ๑Brüggemann)

geothermal energy. This move towards alternative energy sources brought about a boost of creativity and innovation that also captured post-mining areas, because former mining areas offer many opportunities to generate renewable energy.

There are a number of applications already in use.

Research projects work on prototypes, ideas, and visions like:

> Photovoltaic plants on mining areas. Apart from their height, mine dumps have other advantages: there are many free areas and hardly any shade. Therefore, they are ideal locations for photovoltaic systems; the large roofs of factory buildings can be used for these, too (Figure 7.1).

> Heat from minewater. Every year, approximately 70 million cubic metres of minewater is pumped in the Ruhr area. The temperature of this minewater is 35$40^{\circ} \mathrm{C}\left(95-105^{\circ} \mathrm{F}\right)$ and it can be used for supplying heating to buildings by means of heat exchangers, or for accelerating biomass production when generating energy (Figure 7.2).

- Wind turbines on dumps. The dumps in the Ruhr area are often $80-100 \mathrm{~m}$ above the ground surface. Thus, they often feature high wind speeds, which allow for the economically viable use of wind turbines, and some wind turbines have already been erected (Figure 7.3).

> Energy production from methane that is released from coal beds.

> Production of biomass on former mining areas, especially dumps.

> $\quad$ Pumped-storage power plants using dumps and underground mine structures.

>- Production of geothermal energy (Kretschmann and Hegemann, 2012).

\section{Knowledge transfer to South Africa}

Experts in post-mining at TH Georg Agricola University have started knowledge transfer from Germany to the Republic of South Africa. Possible solutions from Germany have been tested for their applicability in South Africa. South Africa has been an exporter of hard coal for over a century. Many abandoned near-surface mines are located in the Mpumalanga Province. According to information from the University of the Witwatersrand (Wits) in Johannesburg, back-calculations from well-documented sales lists of hard coal estimate that there are $1600 \mathrm{~km}^{2}$ of undermined territory; this represents an area measuring $40 \times 40 \mathrm{~km}$. When more than 160 mines (now abandoned) used the normal production method, more than six million pillars supported this area. The average depth of these mines is expected to be between 40 and $80 \mathrm{~m}$. (Otto and Wolf, 2013).

With room and pillar mining there is a high risk of failure of the supporting pillars or the roof. The estimated six million pillars will fail over time, and most of the $1600 \mathrm{~km}^{2}$ area will be disturbed. This poses a latent risk for every kind of surface usage like housing, roads, or farming. Additional

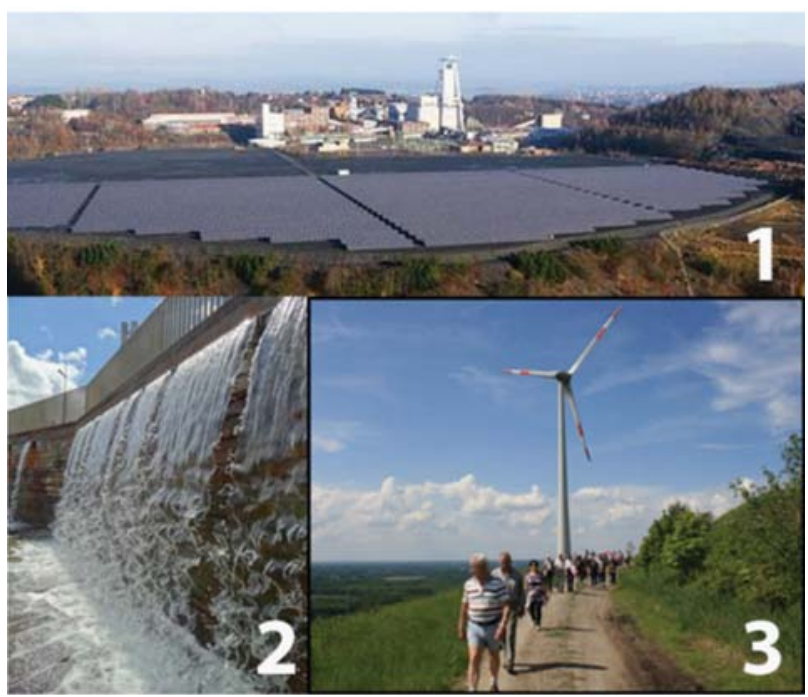

Figure 7-Creating renewable energy, an opportunity of post-mining. (1) Photovoltaic plant on a mud pond; (2) heat from minewater; (3) wind turbine on a dump 


\section{Post-mining excellence: strategy and transfer}

risks exist because of possible self-ignition of the remaining coal in the abandoned mines. During their excursion in 2014, researchers and students of TH Georg Agricola University documented springs of minewater with a temperature of about $35^{\circ} \mathrm{C}$. The Council for Geoscience in Pretoria testified that there is a fire underground at the transition between active mining and abandoned mining areas. Here, the risk of collapsing pillars is high and the air pollution in the working part of the coal mine has adverse health effects (Figure 8).

In addition, during the rainy season, the mined-out cavities close to the surface are flooded with rainwater (Figure 9). The result is that minerals like pyrite are oxidized and dissolved. This dissolution of oxides, especially the sulphur-containing species, is responsible for an acidic $\mathrm{pH}$ of the minewater in the range between 2 and 4 . This acid minewater is able to dissolve heavy metals and salts. At the end of the rainy season, acid minewater with many dissolved minerals flows from the mine sites into the rivers (Otto and Wolf, 2013; Otto, 2015).

From the perspective of risk management, the severity of contamination will rise and the post-mining costs will increase in the future. There is therefore a need to restore the areas disturbed by sinkholes and secure other abandoned mining areas against sinkholes and subsidence. The Council for Geoscience wants to proof the near-surface rooms of abandoned hard coal mines against filling. Therefore a suspension should be used that is able to fill the rooms

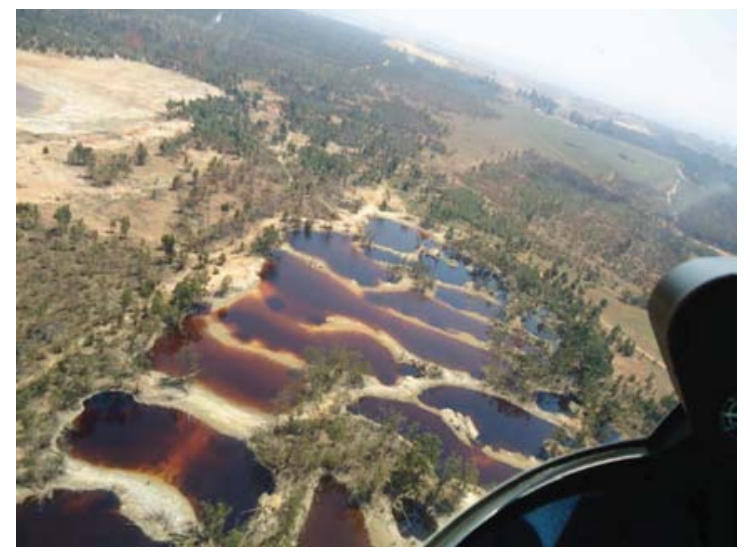

Figure 8-Collapse pits filled with acid minewater (Photo by Henk Coetzee) complete in order to support the roof and stabilize the pillars. The concrete formed from this suspension should have a very low permeability to prevent the infiltration of fresh water. Moreover, the concrete should become hard enough to stay in position even with water flowing over its surface.

To conserve fresh water the suspension could be mixed with the acid water from the abandoned mines, or other innovative and cost-effective methods could be developed. The TH Georg Agricola University has investigated the use of fly ash. To find the right solution the chosen ash needs to be tested for suitability, and the contaminants in the ash analysed. Then, specimens have to be produced using different water qualities and different water-solid ratios in order to test the hardening behaviour (Otto, 2015). The first results are promising, but more research is needed to establish long-lasting sustainable solutions.

\section{Post-mining education - the basis for post-mining excellence}

Post-mining excellence requires high motivation as well as a high level of abilities and skills. Without crucial elements like ideas and vision, research and development, integration of surface and underground challenges, and risk management, post-mining will be inefficient, based on short-term thinking, muddling through, or in the worst case on lip service.

High motivation needs a change of mind-set: post-mining strategy no longer means simply avoiding certain hazards but has to be seen as an evolutionary, sustainable process that is based on the management of risks and the utilization of opportunities. This process should be encouraged by suitable governmental regulations and incentives to promote ideas, to support research and development, and to run high-profile 'flagship' projects profitably. The implementation of such innovative projects at old mine sites is often a milestone for mining communities on their long road to a brighter future. To improve abilities and skills, the existing network of companies, universities, government institutions, mining authorities, and research centres can be used. Its members can promote the transfer of both knowledge and technologies.

In order to competently develop post-mining management, a sufficient number of experts and executives have to be qualified in this field (Figure 10). Therefore, the TH Georg Agricola University offers a unique Master's programme in geo-engineering and post-mining to qualify specialists who will be able to deal with the challenges. The
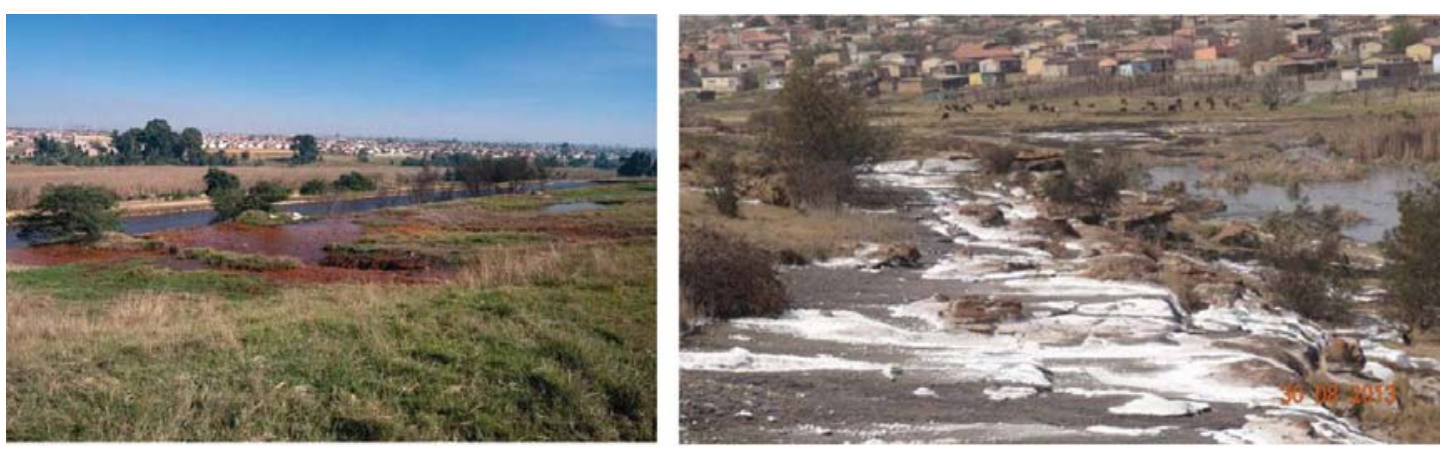

Figure 9-Decant of AMD (acid mine drainage) from the abandoned Transvaal and Delagoa Bay Colliery close to eMalahleni in Mpumalanga. (Right) at the end of dry season and (left) at the end of rainy season (Photos by Henk Coetzee and Frank Otto) 


\section{Post-mining excellence: strategy and transfer}

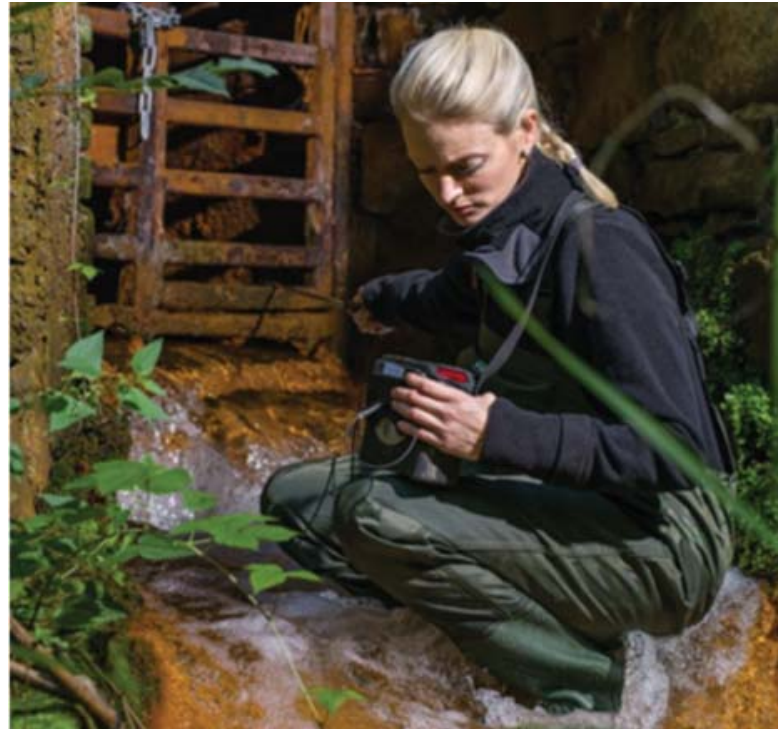

Figure 10-Researcher from TH Georg Agricola University examining minewater from an old adit (TH Georg Agricola, 2017)

study programme combines natural sciences and technology and prepares new experts to cope with complex interdisciplinary issues, from rock mechanics to mineral economics, from hydrogeology to surveying and legal aspects of mine closure. To date, on average 20 students have been enrolled in this programme every year. Furthermore, the University has established a research centre for post-mining (FZN) where new methods of geo-engineering will be developed and tested for sustainable management of mining impacts (Hegemann and Goerke-Mallet, 2014). However, the research centre does not only look at the risks; it also looks at the abovementioned opportunities of post-mining. The research activities are by no means limited to hard coal mining. They include investigating the impacts of all kinds of mining activities. In the long term, socio-economic and spatial aspects will be added to the more technical issues that are currently investigated. Both the Master's programme and research centre are supported by the RAG-Stiftung (Melchers and Goerke-Mallet, 2016).

\section{Conclusion}

RAG, which was established in 1968, will stop producing hard coal after a 50-year period in 2018. To find sustainable solutions for the post-mining era, especially to create good perspectives for the generations to come, RAG has realized a sustainable development strategy that includes numerous measures. The experience and knowledge that the company has gained can be used in many mining regions around the world that will face similar transitions in the future. To develop and transfer knowledge and experience in postmining, the TH Georg Agricola University has established a specific Master's programme and a research centre. South Africa is one of its first partner countries in international knowledge exchange in post-mining. Clearly, every postmining impact has to be examined carefully to find the right solutions for the specific issues on surface and underground, so as to properly deal with the risks and to use the possible opportunities.

\section{Acknowledgement}

I would like to thank my colleague Professor Dr Frank Otto for his support and the insights he gave me into his research in South Africa. As Professor for Geotechnology at the TH Georg Agricola University, he has been one of the first promoters of the Research Institute for Post-Mining. I am convinced that, with his expertise, he can be a promoter to realize post-mining solutions in southern Africa.

\section{References}

Hegemann, M. and Goerke-Mallet, P. 2014. Support of solving the problems of abandoned mining areas in Germany by improvement of the university education. Proceeding of the 33rd International Conference on Ground Control in Mining (China 2014), Beijing, China. pp. 48-54.

KRETSChMAnN, J. 2015. The sustainable development strategy of the German hard coal mining industry. Proceedings of 7 th Sustainable Development in the Minerals Industry Conference (SDIMI), University of British Columbia, Vancouver, Canada. pp. 1-9.

Kretschmann, J. 2014. Stakeholder orientated sustainable land management The Ruhr area as a role model for urban areas. Vestnik, February 2014 pp. 127-132.

Kretschmann, J. and Hegemann, M. 2012. New chances from old shafts. Risk management in abandoned mine sites in Germany. Proceedings of the Annual Meeting of the Society for Mining, Metallurgy \& Exploration, Seattle, Washington, USA. Curran Associates, Red Hook, NY. pp. 153-158.

Melchers, C. and Goerke-Mallet, P. 2016. Research Institute of Post-Mining. TH Georg Agricola University, Bochum, Germany - strategies, activities and research priorities. Done for Good - Challenges of Post-Mining. Anthology by the Research Institute of Post-Mining. TH Georg Agricola University. Bochum. Kretschmann, J. and Melchers, C. (eds). Veröffentlichungen aus dem Deutschen Bergbau-Museum, Bochum. pp. 11-18 [in German].

Отто, F. and WoLf, R. 2013. Mpumalanga - Bergbaufolgeschäden. Bericht fact finding mission 26.08.2013 bis 06.09.2013 September 2013. pp. 1-23.

OTTо, F. 2015. Technologietransfer Nachbergbau aus NRW in die Provinz Mpumalanga in Südafrika (Support for the sanitation of abandoned hard coal mines in South African Province Mpumalanga from German Province North Rhine-Westphalia). Tagungsband 13. BergbauForum Kassel, 18. bis 19.06.2015. DMT Group, Essen. 79 pp..

RAG. 2015. Verantwortung für die Region. Bericht 2015. (Responsibility for the region. Report 2015). RAG, Herne. https://www.rag.de/fileadmin/rag_de/user_upload/DOKUMENTEDWNLD/Downloads_Publikationen/160524_RAG_Online_Nachhaltigkeits bericht_2015_7MB_web_passwort.pdf [accessed 27 October 2017].

RAG. 2017. Geschäftsbericht 2016 (Annual Report 2016). Herne, March 2017 [in German]

RAG-STIFTUNG. 2017. About us. http://www.rag-stiftung.de/en/about-us/ [accessed 10 November 2017]

RAG-STiftung. 2015. Herkunft schafft Zukunft. Geschäftsbericht 2015. (Origin creates future. Annual report 2015). RAG-Stiftung, Essen. http://www.rag-stiftung.de/fileadmin/user_upload/ragstiftung.de/Dokumente/geschaeftsberichte/RAGStiftung_Geschaeftsbericht_2015.pdf [accessed 9 November 2017].

STEINKoHLE. 2016. Kreativer wandel (Creative change). Steinkohle, vol. 10. pp. 7-9 [in German].

StATISTIK DER KoHLENWIRTSCHAFT. 2017. Der Kohlenbergbau in der Energiewirtschaft der Bundesrepublik Deutschland im Jahre 2016 (Coal Mining in the Energy Industry of the Federal Republic of Germany in the year 2016). Essen und Bergheim, November 2017 [in German].

TH Georg Agricola. 2017. Master program: Geotechnical engineering and postmining. https://www.thga.de/en/faculties-of-the-thga/faculty-1-georesources-and-process-engineering/master-programs/geotechnicalengineering-and-post-mining/ [accessed 9 November 2017].

UnITED NATIONS. 1987. Report of the World Commission on Environment and Development: Our Common Future. http://www.un-documents.net/wcedocf.htm [accessed 10 November, 2017]. 